\title{
Synthesis of Niobium Doped Zn0 Nanoparticles by Electrochemical Method: Characterization, Photodegradation of Indigo Carmine Dye and Antibacterial Study
}

\author{
Rakesh'1, Sannaiah Ananda1, Netkal M. Made Gowda², Kithanakere Ramesh Raksha1 \\ ${ }^{1}$ Department of Studies in Chemistry, University of Mysore, Mysore, India \\ ${ }^{2}$ Department of Chemistry, Western Illinois University, One University Circle, Macomb, USA \\ Email: rakesh chemin@yahoo.com, snananda@yahoo.com, gn-made@wiu.edu
}

Received 19 June 2014; revised 13 August 2014; accepted 3 September 2014

Copyright (C) 2014 by authors and Scientific Research Publishing Inc.

This work is licensed under the Creative Commons Attribution International License (CC BY). http://creativecommons.org/licenses/by/4.0/

(c) (i) 0pen Access

\begin{abstract}
Niobium doped Zincoxide nanoparticles has been synthesized through electrochemical method and characterized by UV-Visible spectroscopy, IR Spectroscopy, SEM, XRD, ICPMS and EDAX data. The UV-Visible spectroscopy result reveals that the band gap energy of $\mathrm{ZnO} / \mathrm{Nb}_{2} \mathrm{O}_{5}$ nanoparticles to be $3.8 \mathrm{eV}$. The XRD results show that the crystallite size is to be $31.9 \mathrm{~nm}$. The ICPMS data indicate the presence of 3,3461,328 counts of $93 \mathrm{Nb}$ and 577,906,390 counts of $66 \mathrm{Zn}$. An improvement in the photocatalytic degradation of Indigocarmine dye (IC) in comparison to commercially available pure $\mathrm{ZnO}$ was observed. The photodegradation efficiency for $\mathrm{ZnO} / \mathrm{Nb}_{2} \mathrm{O}_{5}$ and $\mathrm{ZnO}$ were found to be $\mathbf{9 7 . 4 \%}$ and $\mathbf{5 2 . 1 \%}$ respectively. The enhancement in photocatalytic activity of $\mathrm{ZnO} /$ $\mathrm{Nb}_{2} \mathrm{O}_{5}$ was ascribed to the extended light absorption range and suppression of electron hole pair recombination upon $\mathrm{Nb}$ loading. The antibacterial activity of $\mathrm{ZnO} / \mathrm{Nb}_{2} \mathrm{O}_{5}$ nanoparticles was investigated. These particles were shown to have an effective bactericide.
\end{abstract}

\section{Keywords}

$\mathrm{ZnO} / \mathrm{Nb}_{2} \mathrm{O}_{5}$ Nanoparticles, Electrochemical Method, Niobium Coated Platinum Electrode (Pt/Nb), Indigo Carmine Dye (IC), E. coli

\section{Introduction}

$\mathrm{ZnO}$ is a wide-band gap oxide semiconductor with a direct energy gap of about $3.37 \mathrm{eV}$, and as a consequence it

How to cite this paper: Rakesh, Ananda, S., Gowda, N.M.M. and Raksha, K.R. (2014) Synthesis of Niobium Doped ZnO Nanoparticles by Electrochemical Method: Characterization, Photodegradation of Indigo Carmine Dye and Antibacterial Study. Advances in Nanoparticles, 3, 133-147. http://dx.doi.org/10.4236/anp.2014.34018 
absorbs UV radiation due to the band-to-band transitions [1]. Recently, ZnO has attracted growing attention due to its potential applications, such as in ultra-violet light emitting devices and laser devices [2]. Furthermore, ZnO is an environmentally friendly material, in this process, irradiation of semiconductor particles with sufficiently energetic light results in the formation of electron-hole pairs, which can subsequently migrate to the particle surface and react with adsorbed molecules to generate free radicals. These free radicals are highly reactive and can therefore mineralize organic pollutants into harmless compounds, such as $\mathrm{CO}_{2}, \mathrm{H}_{2} \mathrm{O}$ and simple mineral salts [3]-[5].

$\mathrm{ZnO}$ is known to be one kind of the important photo catalysts because of its unique advantages, such as its low price, high photocatalytic activity and nontoxicity, that has attracted a great deal of attention with respect to the degradation of various pollutant due to its high photosensitivity and stability [6]. Among these properties, the degradation of the pollutants catalysed by $\mathrm{ZnO}$ has been studied widely [7]. It has also suggested that $\mathrm{ZnO}$ is a low cost alternative photocatalyst to $\mathrm{TiO}_{2}$ for photodegradation of organics in aqueous solutions [8] [9], as it has a similar band gap energy (3.37 eV) [10] with higher photocatalyst efficiencies was reported [11] [12]. However, the photocatalyst properties of $\mathrm{ZnO}$ for the degradation of pollutant are directly related to their preparation e.g.: particle size, morphology and dopant concentrations.

Electrochemical method is a cost effective and versatile process for controlling the production of nanoparticle materials. This process has been demonstrated as one step, suitable for dry synthesis of high surface area, and highly efficient for noble metal laden catalysts. These advantages of electrochemical method promoted us to apply for production of Nb-loaded $\mathrm{ZnO}$ nanoparticles for photocatalyst in photodegradation of various organic solution. The presence of the loading metal ions/metal oxide in the $\mathrm{ZnO}$ crystalline matrix significantly affects the photocatalyticactivity, charge carries recombination rate and interfacial electron transfer rate [13]. Generally speaking, the metal ions used as dopants are often the transition metal ions, e.g.: Co [14], Mn [15], T [16], La [17], Fe [18], Ni [19], N [20] and so forth. However, no previous work has been reported on the photocatalytic photodegradation of organic contaminants by Nb-loaded ZnO NPs. In present article, we synthesized and report on the photocatalytic degradation behaviour of Indigo carmine on Nb-loaded ZnO nanoparticles under UV-irradiation.

\section{Experimental}

All chemicals used were of the analytical grades of purity, niobium chloride was purchased from Alfa Aesar, Indigo carmine dye from Merck, Zinc metal wire from Alfer Aesar. All solutions were prepared in double distilled water. Absorption spectra was recorded on UV-Visiblespectrophotometer (Shimadzu-1700 series). The FTIR spectra was recorded on Shimadzu IR-affinity-1 by dispersing the nanomaterial in $\mathrm{KBr}(0.3 \mathrm{wt} \%)$. The crystallographic interpretations were performed by X-ray diffractometer (Panalytical X-pert) using Cu k $\alpha$ wavelength $(\lambda=1.5406)$ and scanning range from $23^{\circ}$ to $103.9^{\circ}$. The morphological feature of the semiconductor under study was determined by scanning electron microscopy (ZEISS model). The elemental analysis for the confirmation of loading of Niobium to Zincoxide is conformed from Energy dispersive X-ray analysis (EDAX) and Inductively coupled plasma mass spectroscopy ICPMS (Thermo scientific X-series 2).

\subsection{Electrochemical Synthesis of $\mathrm{ZnO} / \mathrm{Nb}_{2} \mathrm{O}_{5}$ Nanoparticles}

In this method a thin film of niobium was deposited electrochemically on a platinum electrode (Pt/Nb)from niobium chloride solution $(0.1 \mathrm{M})$. The preparation of $\mathrm{ZnO} / \mathrm{Nb}_{2} \mathrm{O}_{5}$ nanoparticles were carried in a reaction chamber containing $20 \mathrm{ml}$ of $\mathrm{NaHCO}_{3}(0.5 \%)$ solution. Voltage power supply of $15 \mathrm{~V}$, current of $22 \mathrm{~mA}$ and $(\mathrm{Pt} / \mathrm{Nb})$ electrode/Zinc wire as anode and Pt electrode as cathode were used. The experiment was run until the complete dissolution of niobium from the platinum plate at constant temperature. The anodic dissolution of $\mathrm{Zn}$ and $\mathrm{Nb}$ gives $\mathrm{Zn}(\mathrm{II})$ and $\mathrm{Nb}(\mathrm{V})$ ions which are electrochemically reacted with aqueous $\mathrm{NaHCO}_{3}(0.5 \%)$ to form $\mathrm{Zn}(\mathrm{II})$ oxides/hydroxide with $\mathrm{Nb}(\mathrm{V})$ oxide. The solid obtained was washed with double distilled water till complete removal of unreacted $\mathrm{NaHCO}_{3}$. The wet powder was then dried at a temperature $250^{\circ} \mathrm{C}-400^{\circ} \mathrm{C}$ for dehydration and removal of hydroxides to get $\mathrm{ZnO} / \mathrm{Nb}_{2} \mathrm{O}_{5}$. The synthesis takes place at the electrodes-electrode interface or close to the electrode within electrical double layer [21]. The product is deposited on the electrode in the form of thin film or coating and also it floats in the electrolyte solution which is collected by filtration [22]. The $\mathrm{pH}$ of the solution before electrolysis was found to be 9.0 which becomes much more alkaline (9.6) after electrolysis because of the formation of alkali $(\mathrm{NaOH})$. The rate of electrochemical reaction is not same for all the metals, as 
the redox potential of $\mathrm{Zn}(-0.7618 \mathrm{v})$ and $\mathrm{Nb}(-1.099 \mathrm{v})$ is different. Since the dissolution potential for $\mathrm{Nb}$ is more negative than $\mathrm{Zn}$, it is expected that the formation of $\mathrm{Nb}_{2} \mathrm{O}_{5}$ takes place in competition with the formation of $\mathrm{ZnO}$. Hence the product would be $\mathrm{ZnO} / \mathrm{Nb}_{2} \mathrm{O}_{5}$ nanoparticle oxide. The electrochemical reaction takes place according to the following mechanism (Scheme 1).

\subsection{Determination of Photocatalytic Activities}

Indigo carmine dye (Molecular formulae: $\mathrm{C}_{16} \mathrm{H}_{8} \mathrm{O}_{8} \mathrm{~N}_{2} \mathrm{~S}_{2}$, Molecular weight: 466.16, $\lambda_{\max }=610 \mathrm{~nm}$ ) solution of (1 $\times 10^{-4} \mathrm{M}$ ) was prepared by dissolving in distilled water. This solution was then used as a test contaminant for investigating photocatalytic activities of the commercial $\mathrm{ZnO}$ and $\mathrm{ZnO} / \mathrm{Nb}_{2} \mathrm{O}_{5}$ nanoparticles. The evaluation was carried out both under UV light and Sunlight in order toinvestigate the efficiency of commercial $\mathrm{ZnO}$ and $\mathrm{ZnO} / \mathrm{Nb}_{2} \mathrm{O}_{5}$ nanoparticles. To examine the photocatalytic activity $5.0 \mathrm{ml}$ of colloidal solution upon exposure to light for equal interval of time were transferred to centrifuge tubes and centrifuged at $800 \mathrm{rpm}$ to remove the dispersed catalyst and percent transmission was recorded for the colour solution. Chemical oxygen demand (COD) was estimated before and after treatment using dichromate oxidation method [23]. The increase in percent transmission and decrease in COD (mg/l) of dye solution with colour removal was observed to be more in $\mathrm{ZnO} / \mathrm{Nb}_{2} \mathrm{O}_{5}$ compared to commercial $\mathrm{ZnO}$ material.

\section{Results and Discussion}

\subsection{Uv-Visible Spectra}

Uv-Visible spectrum (Figure 1) of $\mathrm{ZnO} / \mathrm{Nb}_{2} \mathrm{O}_{5}$ over the range 200 - $800 \mathrm{~nm}$ showed photoabsorption properties no longer than $240 \mathrm{~nm}$, which suggest that the catalyst is photo active under UV light irradiation. Assuming the

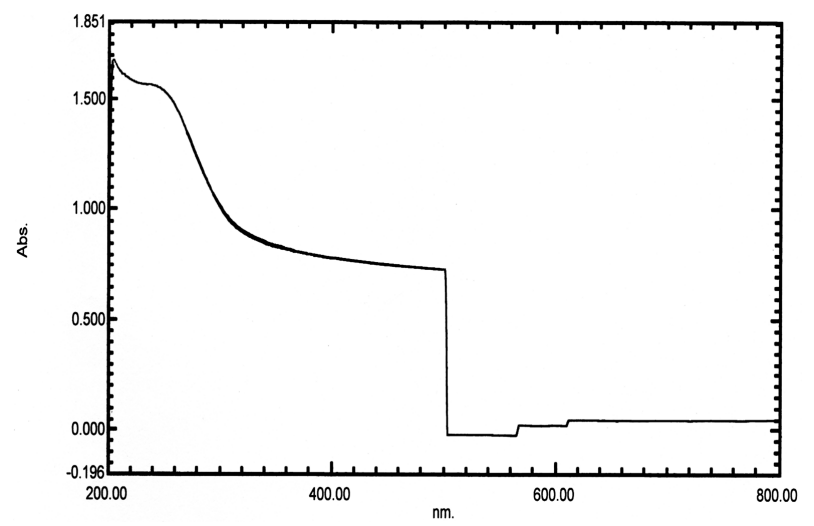

Figure 1. Uv-Vis spectrum of $\mathrm{ZnO} / \mathrm{Nb}_{2} \mathrm{O}_{5}$.

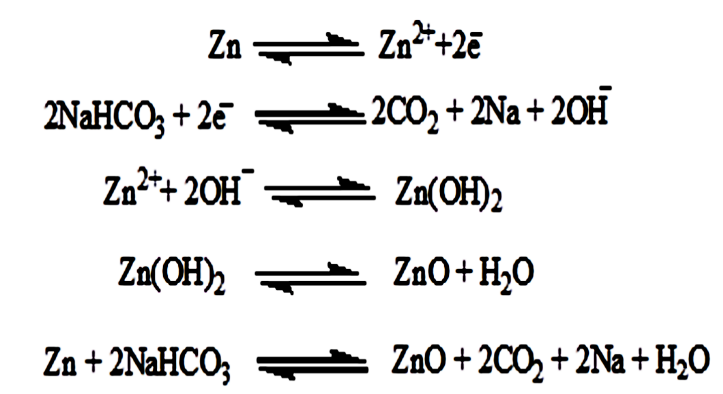

Similarly, $2 \mathrm{Nb}+10 \mathrm{NaHCO}_{3}=\mathrm{Nb}_{2} \mathrm{O}_{5}+10 \mathrm{CO}_{2}+10 \mathrm{Na}+5 \mathrm{H}_{2} \mathrm{O}$
The overall reaction is, $\mathrm{Zn}+2 \mathrm{Nb} \stackrel{\mathrm{NaHCO}_{3}}{\longrightarrow} \mathrm{ZnONb}_{2} \mathrm{O}_{5}$

Scheme 1. Probable mechanism for synthesis of $\mathrm{ZnO} / \mathrm{Nb}_{2} \mathrm{O}_{5}$ nanoparticles. 
$\mathrm{ZnO} / \mathrm{Nb}_{2} \mathrm{O}_{5}$ solid asdirect semiconductor and it is possible to calculate the band gap of $\mathrm{ZnO} / \mathrm{Nb}_{2} \mathrm{O}_{5}$ by constructing a Tauc plot [24]. The Tauc plot of $\mathrm{ZnO} / \mathrm{Nb}_{2} \mathrm{O}_{5}$ is displayed in Figure 2. The energy of the band gap could be thus estimated to be $3.8 \mathrm{eV}$ for $\mathrm{ZnO} / \mathrm{Nb}_{2} \mathrm{O}_{5}$. $\mathrm{ZnO} / \mathrm{Nb}_{2} \mathrm{O}_{5}$ is slightly greyish in colour. It is reported that $\mathrm{Nb}$ loading results in enlarge surface area of the $\mathrm{Nb}$-loaded $\mathrm{ZnO}$ photocatalyst. However, the increase of surface area is likely not the main factor affecting the photocatalytic activity of Nb-loaded $\mathrm{ZnO}$. Other factor that could affect photocatalytic efficiency are such as availability of active sites, crystalline structure, pore size and number/nature of trapped sites [25] [26]. According to the literatures and the fact that niobium acting as an electron trap [27], an enhanced photocatalytic activity of Nb-loaded $\mathrm{ZnO}$ nanoparticles found in our study was likely ascribed to a decrease of electron-hole pair recombination and thus promoting the photocatalytic activity [28].

\subsection{Infrared Spectra}

Figure 3 represents the IR spectrum of the $\mathrm{ZnO} / \mathrm{Nb}_{2} \mathrm{O}_{5}$ nanoparticles. Metal oxides generally give absorption bands below $1000 \mathrm{~cm}^{-1}$ arising from interatomic vibrations. A band around $450 \mathrm{~cm}^{-1}$ corresponds to $\mathrm{Zn}-\mathrm{O}$ bonds. A peak at $708 \mathrm{~cm}^{-1}$ and $941 \mathrm{~cm}^{-1}$ corresponds to Nb-O bending and stretching vibrations. The peak at $1120 \mathrm{~cm}^{-1}$ indicates the formation of $\mathrm{ZnO}$. A peak at $2360 \mathrm{~cm}^{-1}$ corresponds to the absorbed of $\mathrm{CO}_{2}$ on the metallic cations.

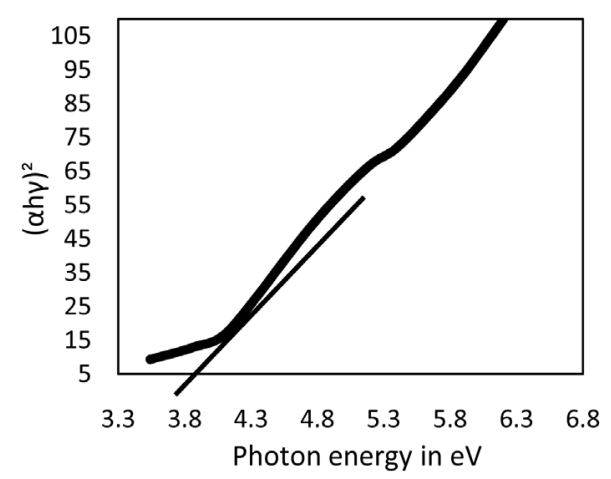

Figure 2. Tauc plot of $\mathrm{ZnO} / \mathrm{Nb}_{2} \mathrm{O}_{5}$.

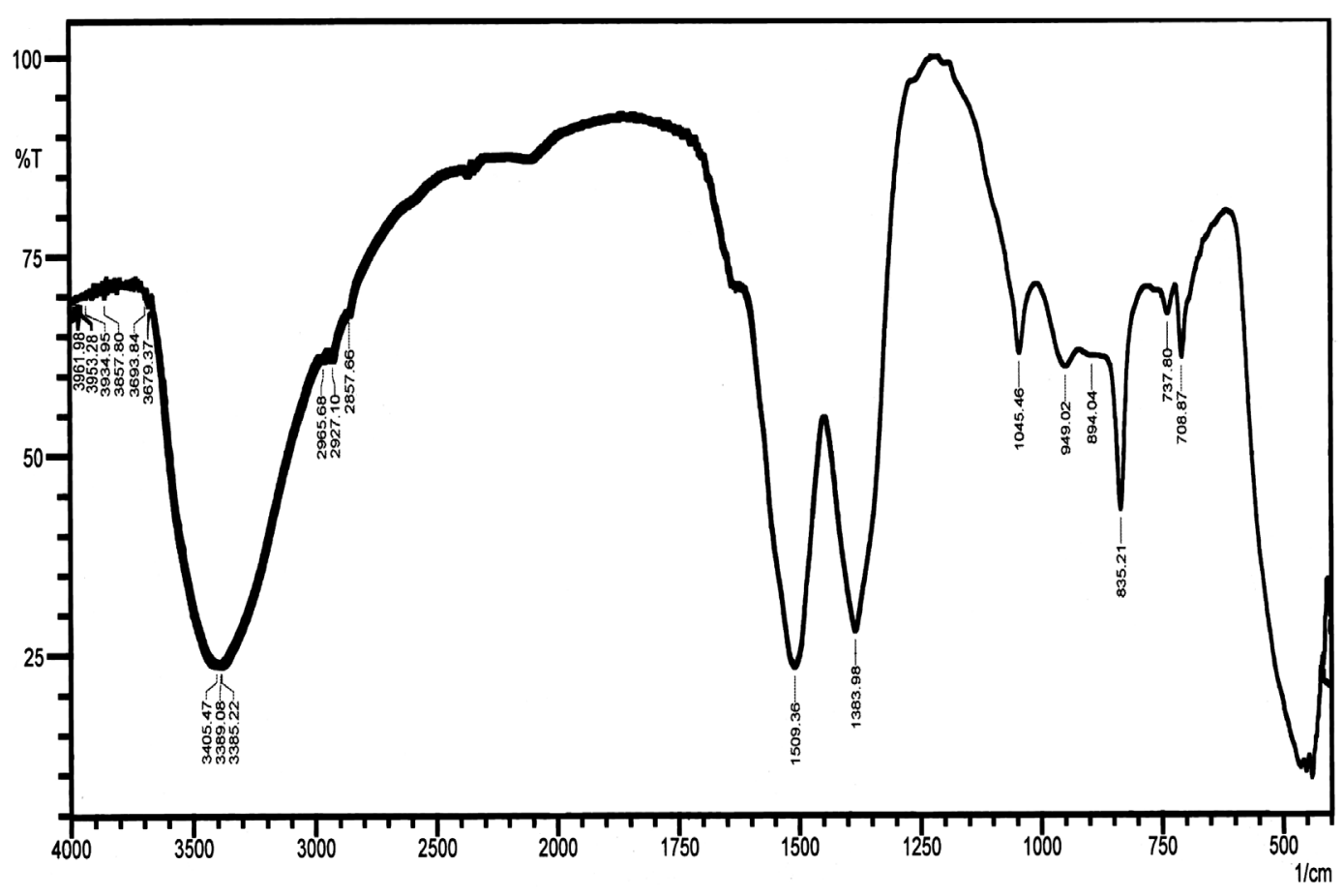

Figure 3. IR spectra of $\mathrm{ZnO} / \mathrm{Nb}_{2} \mathrm{O}_{5}$ nanoparticles. 
A peak at $1630 \mathrm{~cm}^{-1}$ and $3500-3800 \mathrm{~cm}^{-1}$ indicates the presence of water molecules and hydroxyl radicals respectively on the surface of the $\mathrm{ZnO} / \mathrm{Nb}_{2} \mathrm{O}_{5}$ nanoparticles. The $\mathrm{M}-\mathrm{O}$ frequencies observed for nanoparticles of metal oxides are in accordance with literature values [29].

\subsection{X-Ray Diffraction}

XRD pattern of $\mathrm{ZnO} / \mathrm{Nb}_{2} \mathrm{O}_{5}$ is shown in Figure 4, it exhibits dominant diffraction peaks. The (hkl) values according to Treor programming (IUCR) of the peaks $28.15^{\circ}, 31.88^{\circ}, 34.4^{\circ}, 36.2^{\circ}, 47.5^{\circ}, 58.2^{\circ}, 62.8^{\circ}$ and $67.9^{\circ}$ corresponds to the crystal planes of (111), (201), (020), (310), (320), (222), (330) and (511) respectively. The crystallite size of $\mathrm{ZnO} / \mathrm{Nb}_{2} \mathrm{O}_{5}$ was found to be $31.9 \mathrm{~nm}$, the unit cell volume is $334 \AA^{3}$, and $\alpha=\gamma=90^{\circ} \neq \beta, \mathrm{a} \neq \mathrm{b}$ f c, $\left(\mathrm{a}=10.39 \AA, \mathrm{b}=5.203 \AA, \mathrm{c}=7.608 \AA\right.$ ). Accordingly $\mathrm{ZnO} / \mathrm{Nb}_{2} \mathrm{O}_{5}$ belongs to monoclinic crystal system. The diffraction peaks at $28.15^{\circ}, 36.2^{\circ}$, and $58.2^{\circ}$ corresponds to $\mathrm{Nb}$ phase are seen in XRD pattern of $\mathrm{ZnO} /$ $\mathrm{Nb}_{2} \mathrm{O}_{5}$ nanoparticles which confirms the presence of $\mathrm{Nb}(\mathrm{V})$ in $\mathrm{ZnO}$ matrix [30].

\subsection{Inductively Coupled Plasma-Mass Spectroscopy}

The elemental analysis of $\mathrm{ZnO} / \mathrm{Nb}_{2} \mathrm{O}_{5}$ nanoparticles was carried out using Thermo scientific-X-series 2 with plasma lab software. The results shows the loading of niobium to the zinc oxide matrix in terms of atomic counts, where $50.0 \mathrm{mg}$ of nanoparticles were dissolved in $50 \mathrm{ml}$ of $2 \% \mathrm{HNO}_{3}$ solution and the above solution was aspirated to the instrument after the blank analysis. The analysis was carried out in triplet and atomic count, mean and \% RSD has been tabulated in Table 1.

Thus the above data confirms the presence of Niobium in $\mathrm{ZnO}$ matrix. The instrument parameters used for performing the analysis is shown in Table 2.

Table 1. ICP-MS results for the loading of Niobium to $\mathrm{ZnO}$ matrix.

\begin{tabular}{ccc}
\hline Run & $66 \mathrm{Zn}$ & $93 \mathrm{Nb}$ \\
\hline 1 & 572875130.00 & 33040528.00 \\
2 & 574806010.00 & 33201860.00 \\
3 & 586038030.00 & 34141598.00 \\
$\mathrm{X}$ & 577906390.00 & 33461328.00 \\
$\sigma$ & 7108077.900 & 594627.530 \\
\hline RSD & 1.230 & 1.777 \\
\hline
\end{tabular}

Table 2. Instrumental parameters for the analysis of $\mathrm{ZnO} / \mathrm{Nb}_{2} \mathrm{O}_{5}$.

\begin{tabular}{|c|c|}
\hline Plasma gas flow & 13.0 liter/minute \\
\hline Auxiliary gas flow & 0.7 liter/Minute \\
\hline Nebulizer pressure & $0.9 \mathrm{bar}$ \\
\hline Pump speed & $40 \mathrm{rpm}$ \\
\hline Sample uptake delay & 30 seconds \\
\hline Plasma power & $1.4 \mathrm{Kw}$ \\
\hline Nebulizer & Concentric \\
\hline Acquisitiontime (Dwell time) & 30 milli seconds/channel \\
\hline Number of channel & 3 \\
\hline Channel spacing & $0.02 \mathrm{Amu}$ \\
\hline
\end{tabular}




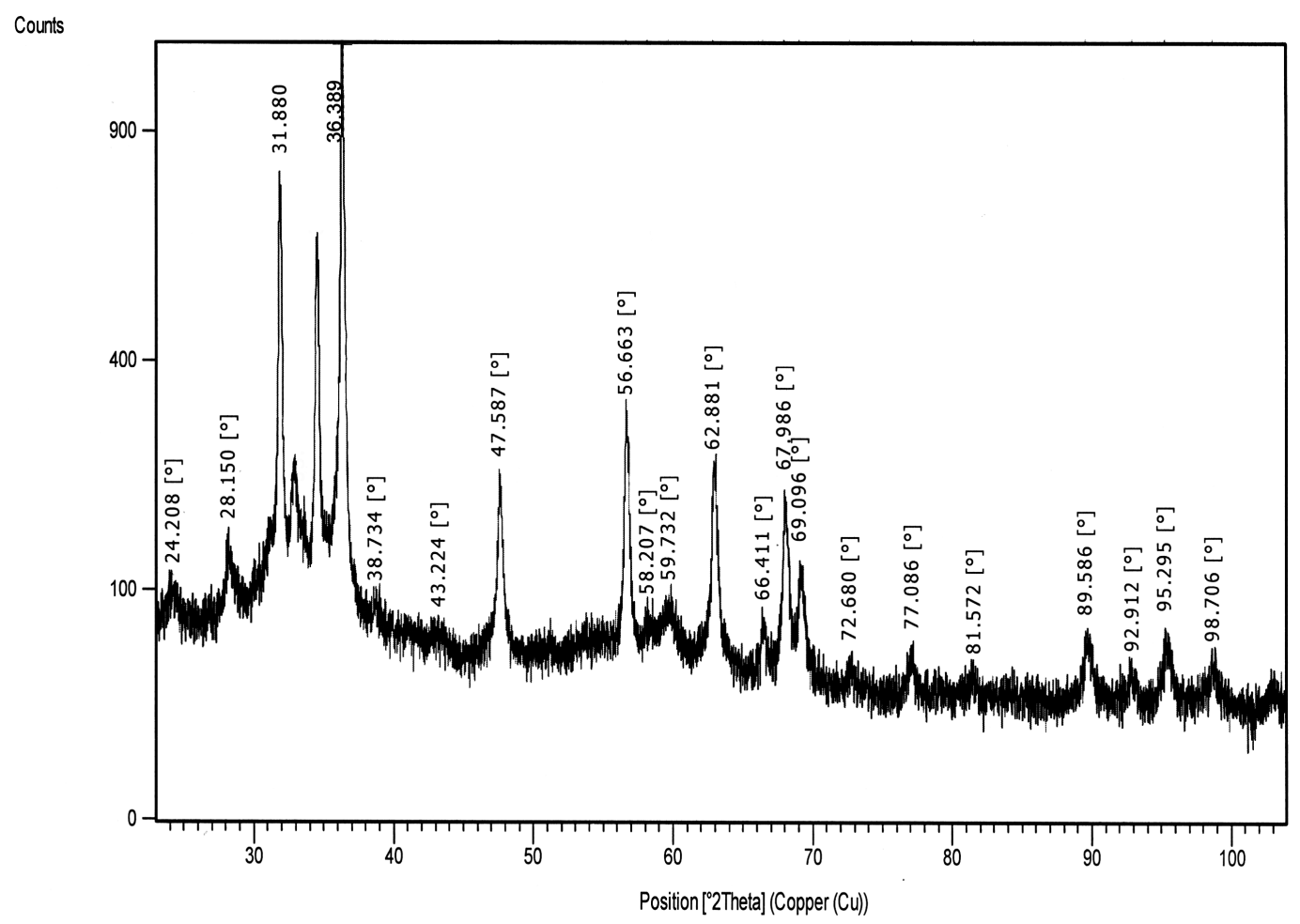

Figure 4. XRD pattern of $\mathrm{ZnO} / \mathrm{Nb}_{2} \mathrm{O}_{5}$ nanoparticles.

\subsection{Scanning Electron Microscopy (SEM)}

Scanning electron microscopy was used to study the surface morphology of $\mathrm{ZnO} / \mathrm{Nb}_{2} \mathrm{O}_{5}$ nanoparticles. A scanning electron microscope (ZESIS) was employed to characterize the sample. A numerous nanorods with bundle-like structures were formed as depicted in Figure 5. These nanorods lies close to each other and their lengths upto several micrometres.

\subsection{Energy Dispersive X-Ray Analysis}

The elemental analysis of the $\mathrm{ZnO} / \mathrm{Nb}_{2} \mathrm{O}_{5}$ nanoparticles was carried out using EDAX (JOEL, JED-2300, Germany). The EDAX analysis shows presence of only $\mathrm{Zn}, \mathrm{Nb}$ and $\mathrm{O}$ as expected, no other impurity elements were present in the $\mathrm{ZnO} / \mathrm{Nb}_{2} \mathrm{O}_{5}$ nanoparticles (Figure 6).

The mass\% of $\mathrm{Zn}$ and $\mathrm{O}$ in sample was not as per stoichiometric proportion. The entire sample were observed to be oxygen deficient. The deficiency or excess of the constituent material results in distorted band structure with corresponding increase in conductivity. Zinc oxide loses oxygen on heating so that the zinc is in excess. The oxygen of course evolves as electrically neutral substance so that it is associated with each excess zinc ion in the crystal; there will be two electrons that remain trapped in the solid material, thus leading to non-stoichiometricity in the solid. This leads to the formation of the semiconducting nature of the material [31].

\section{Photodegradation and COD Measurements}

The percent transmission of dye solution in presence of $\mathrm{ZnO} / \mathrm{Nb}_{2} \mathrm{O}_{5}$ at different intervals of time is much higher as compared to solutions with $\mathrm{ZnO}$. Thus, photocatalytic degradation is favourably affected by $\mathrm{ZnO} / \mathrm{Nb}_{2} \mathrm{O}_{5}$ (Figure 7). A plot of $\log \mathrm{T}$ versus time is linear, hence the reaction follows pseudo first order kinetics. The rate of photodegradation for $\mathrm{ZnO} / \mathrm{Nb}_{2} \mathrm{O}_{5}$ was observed to be $9.67 \times 10^{-5} \mathrm{sec}^{-1}$ ( $\sim 97 \%$ reaction) which is higher than the value obtained for $\mathrm{ZnO} 5.77 \times 10^{-5} \mathrm{sec}^{-1}$.

\subsection{Effect of Concentration of Indigo Carmine Dye}

The reaction was performed with different concentrations of Indigo carmine with constant weight of $\mathrm{ZnO} / \mathrm{Nb}_{2} \mathrm{O}_{5}$ 

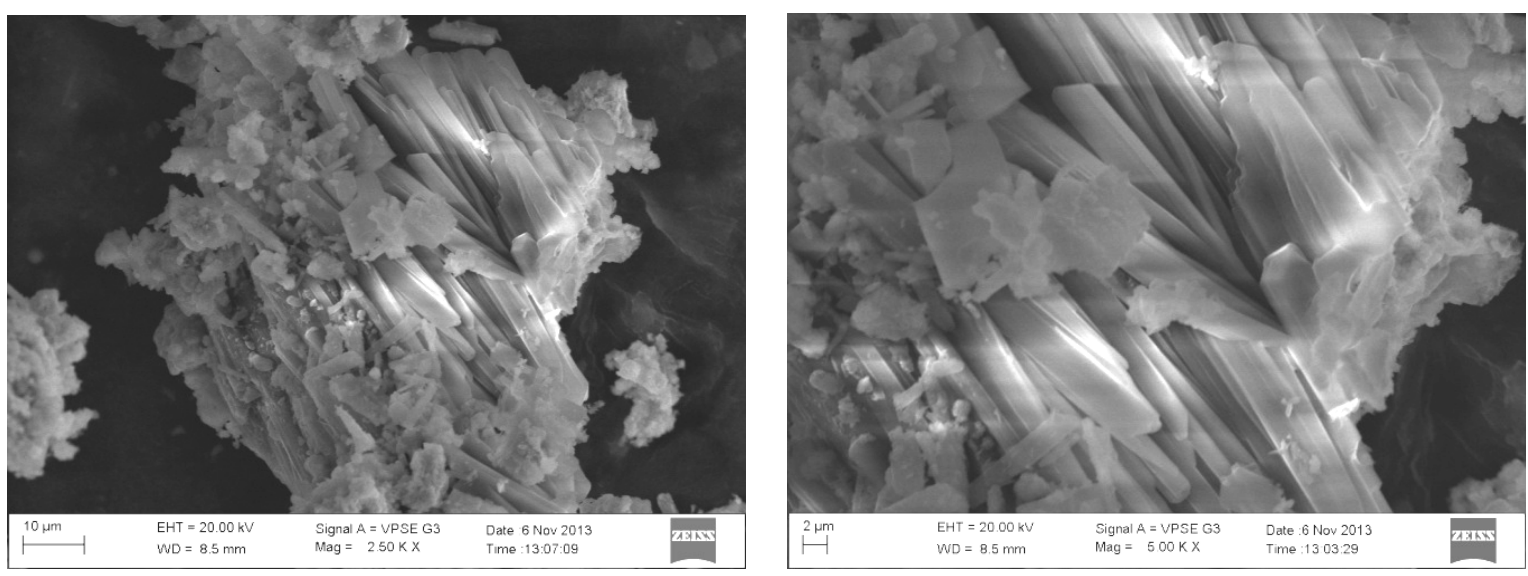

Figure 5. SEM images of $\mathrm{ZnO} / \mathrm{Nb}_{2} \mathrm{O}_{5}$ nanoparticles.

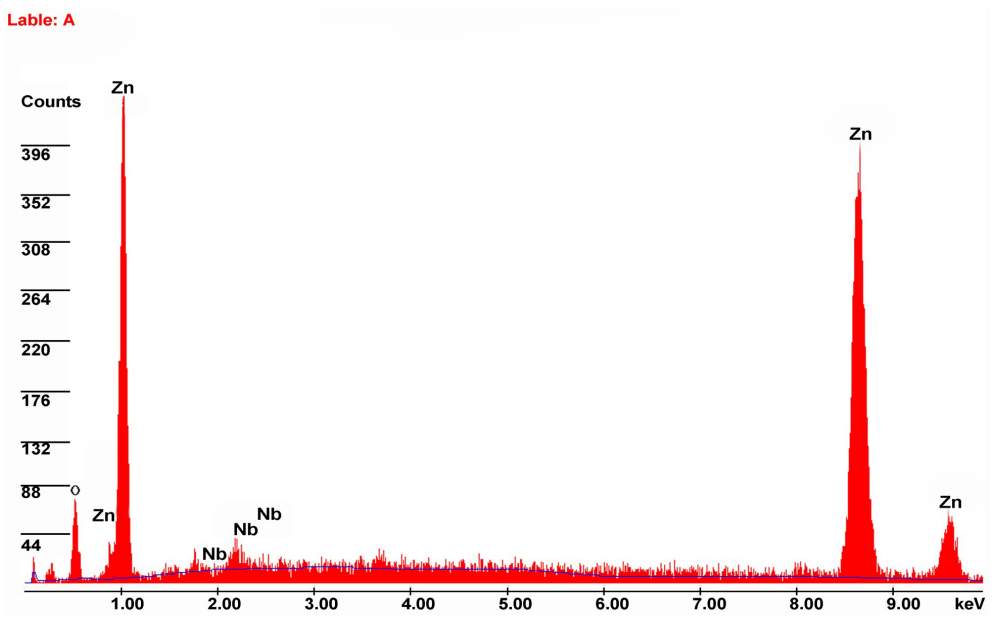

Figure 6. EDAX spectra of $\mathrm{ZnO} / \mathrm{Nb}_{2} \mathrm{O}_{5}$ nanoparticles.

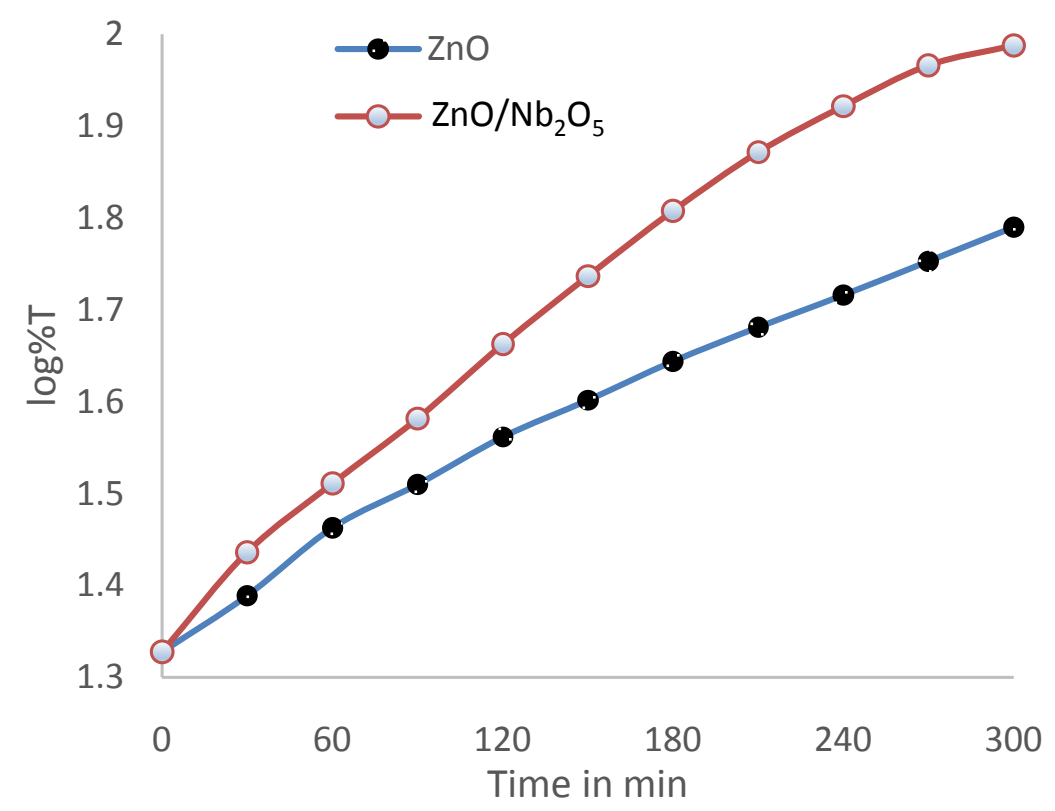

Figure 7. Photodegradation kinetics of indigo carmine dye. 
catalyst. The change in concentration of the Indigo carmine was recorded by change in colour using Spectrophotometer. A plot of log\%T (percent transmittance of light) versus time was liner up to $60 \%$ of the reaction indicating the disappearance of IC follows first order kinetics (Figure 8). The rate constant values are tabulated in Table 3 and the reaction rate decreases with increase in concentration of IC. This is because with increase in the dye concentration, the solution becomes more intensely colour and the path length of the photons entering the solution is decreased thereby few photons reaches the catalyst surface. Hence the production of hydroxyl radicals is reduced. Therefore the photodegradation efficiency is reduced. The $\mathrm{pH}$ and $C O D$ for IC solutions before and after degradation were measured and given in Table 3.

To account for the mineralization of dye $C O D$ was determined at different stage. The formation of different radical species during photodegradation is given in Scheme 2. The dye was found to have mineralized into $\mathrm{H}_{2} \mathrm{O}$, $\mathrm{CO}_{2}$ and simpler inorganic salts [32], after being irradiated for 5 hrs using $\mathrm{ZnO} / \mathrm{Nb}_{2} \mathrm{O}_{5}$ photocatalyst. The photodegradation efficiency of the photocatalyst was calculated by the following formula (Figure 9).

$$
\text { Photodegradation efficiency }=\frac{\text { Initial } C O D-\text { Final } C O D}{\text { Initial } C O D} \times 100
$$

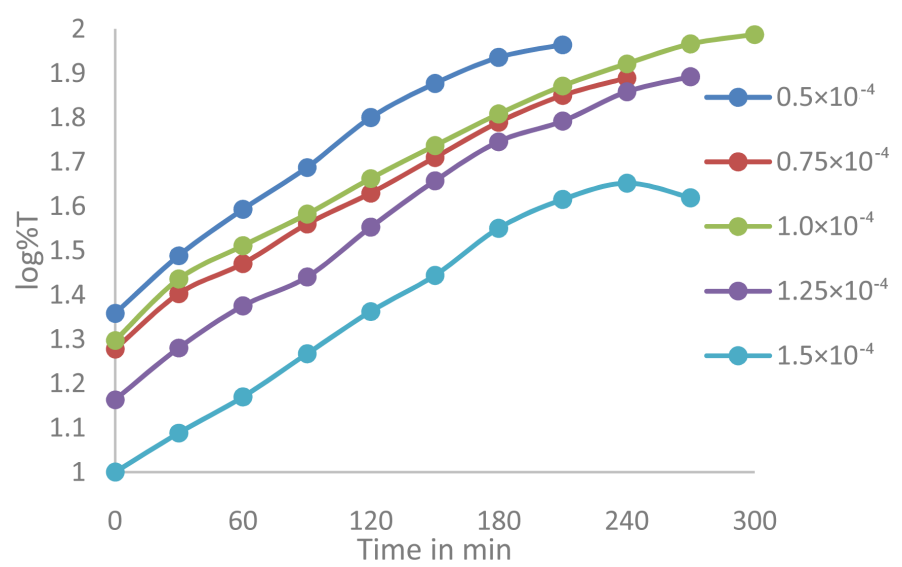

Figure 8. Effect of concentration of IC on the rate of degradation.

1400

1200

- Before degradation

- After degradation

1000

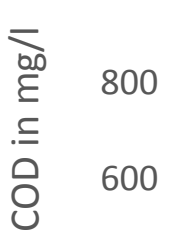

400

200

0

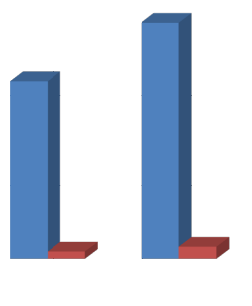
0.5
Conc in $10^{-4}$

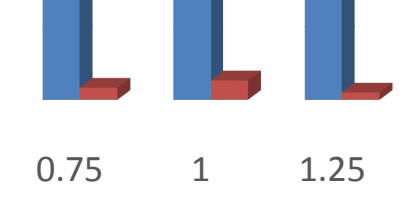

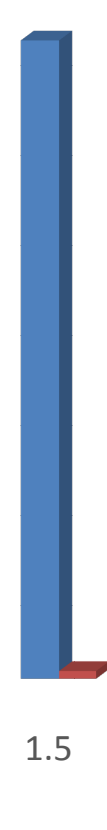

Figure 9. Effect of concentration of IC on COD values. 


$$
\begin{aligned}
& \mathrm{e}_{\mathrm{cb}}+\mathrm{O}_{2} \longrightarrow \mathrm{O}_{2}^{-} \\
& \mathrm{H}_{\mathrm{vb}}+\mathrm{H}_{2} \mathrm{O} \longrightarrow \mathrm{H}^{+}+{ }^{\circ} \mathrm{OH} \\
& \mathrm{O}_{2}^{-}+\mathrm{H}^{+} \longrightarrow \mathrm{HO}_{2}^{\cdot} \\
& \dot{\mathrm{HO}}_{2}+\overline{\mathrm{e}}_{\mathrm{cb}}+\mathrm{H}^{+} \longrightarrow \mathrm{H}_{2} \mathrm{O}_{2} \\
& \mathrm{H}_{2} \mathrm{O}_{2}+\mathrm{O}_{2}^{-} \longrightarrow \mathrm{OH}^{-} \mathrm{OH}+\mathrm{O}_{2} \\
&{ }_{\mathrm{OH}} \longrightarrow \mathrm{Dye} \longrightarrow \mathrm{CO}_{2}+\mathrm{H}_{2} \mathrm{O}+\text { Simpler inorganic salts }
\end{aligned}
$$

Scheme 2. Mechanism for the photodegradation of Dye.

Table 3. Effect of photodegradation at different concentration of Indigo carmine.

\begin{tabular}{cccccc}
\hline \multirow{2}{*}{$10^{-4}[\mathrm{IC}]$} & $\mathrm{ksec}^{-1}$ & \multicolumn{2}{c}{ Effect of $\mathrm{pH}$} & \multicolumn{2}{c}{ COD values in mg/l } \\
\cline { 3 - 6 } & & Before degradation & After degradation & Before degradation & After degradation \\
\hline 0.5 & $12.1 \times 10^{5}$ & 6.95 & 6.14 & 370 & 25 \\
0.75 & $10.1 \times 10^{5}$ & 7.32 & 6.89 & 490 & 710 \\
1.0 & $9.67 \times 10^{5}$ & 7.68 & 6.93 & 930 & 15 \\
1.25 & $7.61 \times 10^{5}$ & 7.83 & 6.82 & 6.75 & 1327 \\
1.5 & $5.81 \times 10^{5}$ & 7.95 & & 16 \\
\hline
\end{tabular}

\subsection{Effect of $\mathrm{pH}$}

The solution $\mathrm{pH}$ is an important variable in the evaluation of aqueous phase mediated photocatalytic reactions. The $\mathrm{pH}$ of the solution was adjusted by adding $0.001 \mathrm{M} \mathrm{HNO}_{3}$ or $0.001 \mathrm{M} \mathrm{NaOH}$ solution. The effect of $\mathrm{pH}$ was studied at $\mathrm{pH}$ 7.02, $\mathrm{pH}$ 6.02, $\mathrm{pH} 9.02$ and $\mathrm{pH} 10.02$ by keeping all other experimental conditions constant. The results are illustrated in Figure 10 and tabulated in Table 4. The rate of degradation is observed to be slow at lower $\mathrm{pH}(<7.02)$ and higher $(>9.02) \mathrm{pH}$. It was observed that the amount of material recovered after the experiment was lowered at lower and higher $\mathrm{pH}$ because of the dissolution of semiconductor oxides at extreme $\mathrm{pH}$ values. Results of COD effects are illustrated in Figure 11. The optimum selected is 10.02 at which photodegradation is high.

\subsection{Effect of Catalyst Loading}

The experiments were performed by taking different amount of catalyst varying from $3.0 \mathrm{mg}$ to $7.0 \mathrm{mg}$ in order to study the effect of catalyst loading. The study showed that increase in catalyst loading from $3.0 \mathrm{mg}-7.0 \mathrm{mg}$ increased dye removal efficiency. Further increase in catalyst above $7.0 \mathrm{mg}$ decreased the photoactivity of the catalyst, which is due to the aggregation of $\mathrm{ZnO} / \mathrm{Nb}_{2} \mathrm{O}_{5}$ nanoparticles at high concentration causing a decrease in the number of surface active sites and increase in the opacity and light scattering of $\mathrm{ZnO} / \mathrm{Nb}_{2} \mathrm{O}_{5}$ nanoparticles at high concentration. This tends to decrease the passage of light through the sample. Further, in the present study indicated, from economic point of view, the optimized photocatalyst loading is $7.0 \mathrm{mg} / 20 \mathrm{ml}$ (Figure 12 and Table 5). A result of COD effect is illustrated in Figure 13.

\subsection{Effect of Light Intensity}

The photodegradation rate with UV light is compared with sunlight. It is observed that the photodegradation rate is increased in UV light for prepared photocatalysts compared to ZnO (Figure 14 and Figure 15, Table 6). The reason is that, the inclusion of $\mathrm{Nb}^{5+}$ in $\mathrm{ZnO}$ matrix caused an increase in the band gap of $\mathrm{ZnO}$ from $3.3 \mathrm{eV}$ to 3.8 $\mathrm{eV}$, indicating that these semiconductor nanoparticles absorb UV light. This can subsequently activate these modified metal oxide photocatalysts upon UV light irradiation. When a photon incident on a semiconductor $\left(\mathrm{ZnO} / \mathrm{Nb}_{2} \mathrm{O}_{5}\right)$ has energy that matches or exceeds the band gap energy of the semiconductor, an $\mathrm{e}^{-}$is promoted from the valence band (VB) into the conduction band (CB), leaving a hole in the VB. Excited-state CB electrons and VB holes can recombine and dissipate the input energy as heat, get trapped in metastable surface states, or 


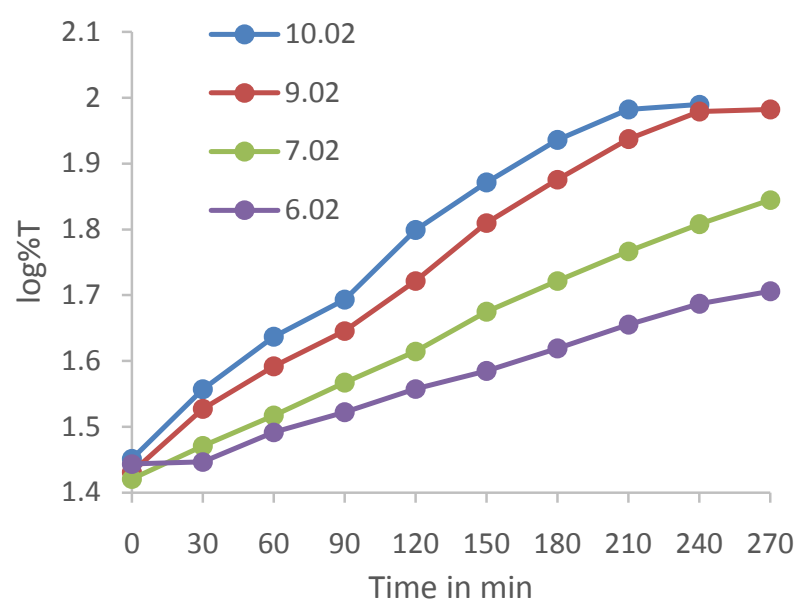

Figure 10. Effect of $\mathrm{pH}$ on the rate of degradation of IC.

Table 4. Effect of pH on photodegradation of Indigo carmine.

\begin{tabular}{ccccc}
\hline \multirow{2}{*}{$\mathrm{pH}$} & \multirow{2}{*}{$\mathrm{ksec}^{-1} 10^{5}$} & \multicolumn{2}{c}{ COD values in mg/l } & Photodegradation efficiency \% \\
\cline { 3 - 4 } & 4.47 & 730 & After degradation & 94.79 \\
\hline 6.02 & 6.39 & 730 & 38 & 94.79 \\
9.02 & 9.38 & 730 & 16 & 97.80 \\
10.02 & 11.0 & 730 & 16 & 97.80 \\
\hline
\end{tabular}

Table 5. Effect of catalyst loading on the photodegradation of IC.

\begin{tabular}{|c|c|c|c|c|c|}
\hline \multirow{2}{*}{ Catalyst $\left(\mathrm{ZnO} / \mathrm{Nb}_{2} \mathrm{O}_{5}\right)$ in $\mathrm{mg}$} & \multirow{2}{*}{$\mathrm{ksec}^{-1}$} & \multicolumn{2}{|c|}{ Effect of $\mathrm{pH}$} & \multicolumn{2}{|c|}{ COD in $\mathrm{mg} / \mathrm{l}$} \\
\hline & & Before degradation & After degradation & Before degradation & After degradation \\
\hline 3.0 & $4.51 \times 10^{5}$ & 7.72 & 6.51 & 710 & 32 \\
\hline 4.0 & $7.63 \times 10^{5}$ & 7.75 & 6.72 & 710 & 16 \\
\hline 6.0 & $10.4 \times 10^{5}$ & 7.80 & 6.83 & 710 & 32 \\
\hline 7.0 & $11.1 \times 10^{5}$ & 7.85 & 6.95 & 710 & 16 \\
\hline
\end{tabular}

Table 6. Effect of photodegradation at different concentration of IC under sunlight.

\begin{tabular}{cccccc}
\hline \multirow{2}{*}{$10^{-4}[\mathrm{IC}]$} & $\mathrm{sec}^{-1}$ & \multicolumn{2}{c}{ Effect of $\mathrm{pH}$} & \multicolumn{2}{c}{ COD values in mg/l } \\
\cline { 3 - 6 } & & Before degradation & After degradation & Before degradation & After degradation \\
\hline 0.5 & $4.19 \times 10^{5}$ & 6.97 & 6.15 & 370 & 16 \\
0.75 & $4.13 \times 10^{5}$ & 7.34 & 6.90 & 490 & 32 \\
1.0 & $3.88 \times 10^{5}$ & 7.68 & 6.89 & 710 & 930 \\
1.25 & $3.05 \times 10^{5}$ & 7.82 & 6.83 & 1327 & 32 \\
1.5 & $2.99 \times 10^{5}$ & 7.91 & 6.75 & & 32 \\
\hline
\end{tabular}




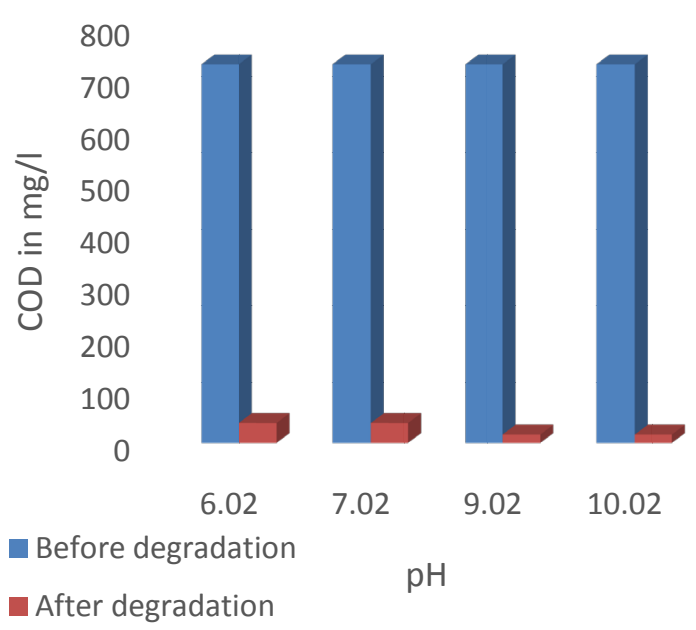

Figure 11. Effect of $\mathrm{pH}$ on COD values.

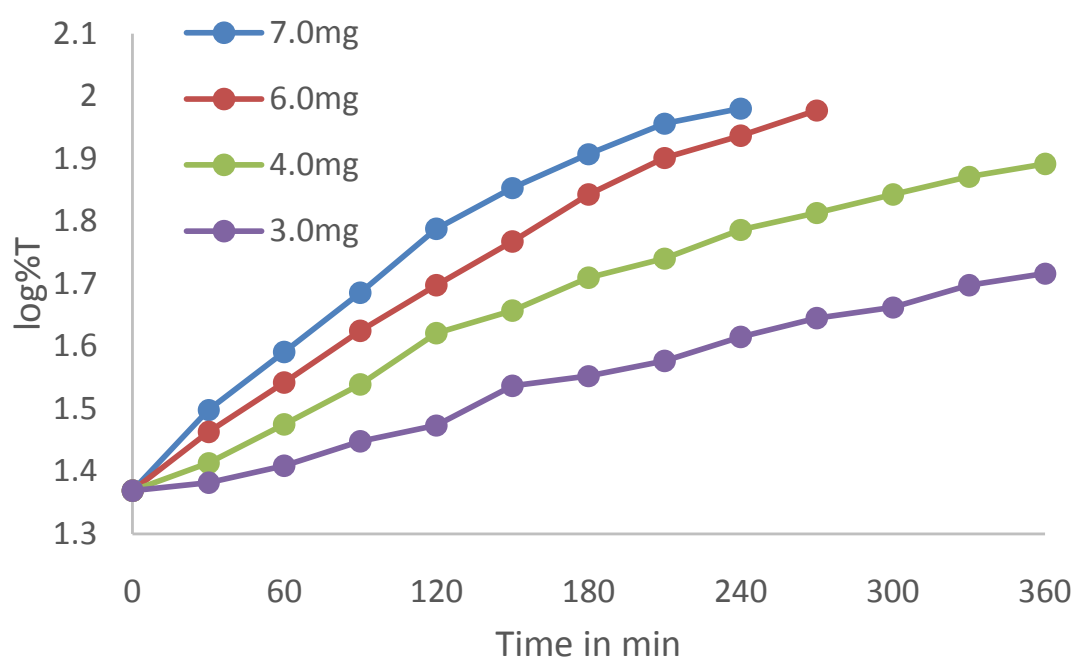

Figure 12. Effect of catalyst loading on photodegradation of IC.

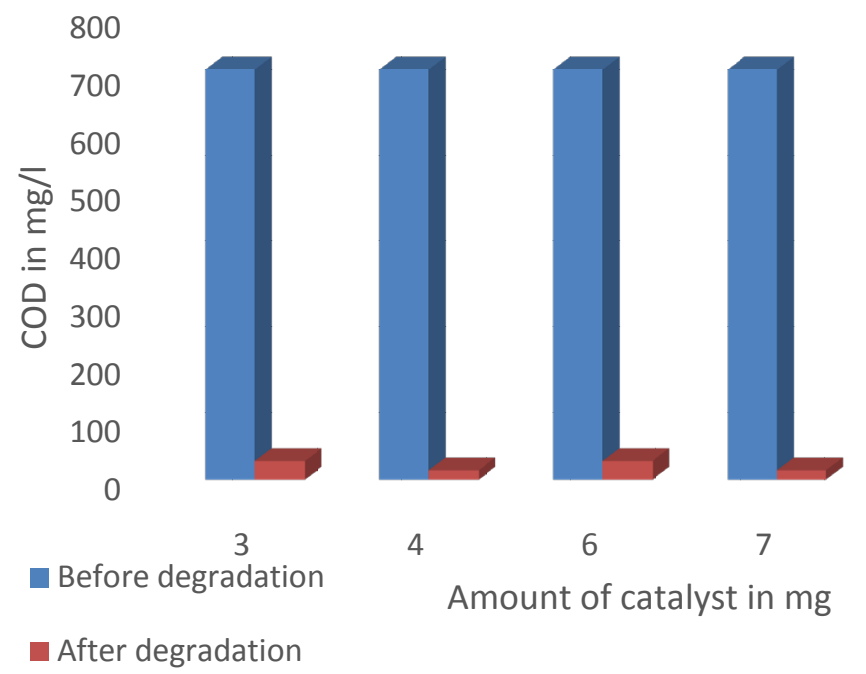

Figure 13. Effect of catalyst loading on COD values for the degradation of IC. 


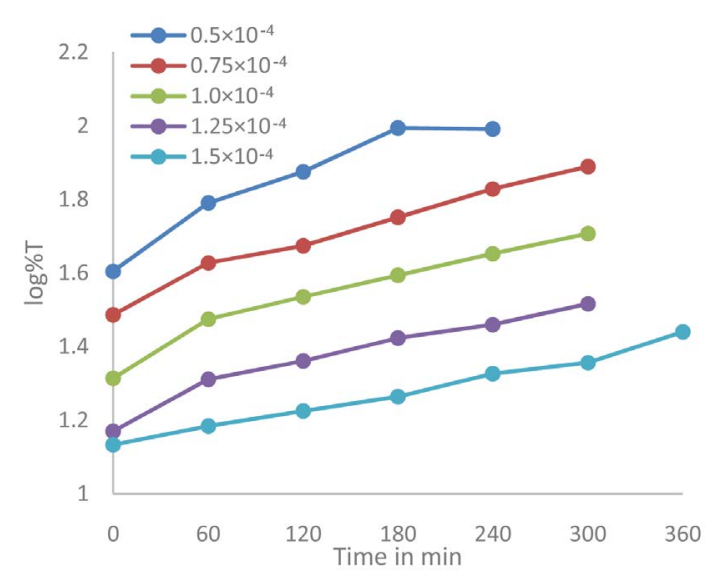

Figure 14. Effect of concentration on IC on the rate of degradation in sunlight.

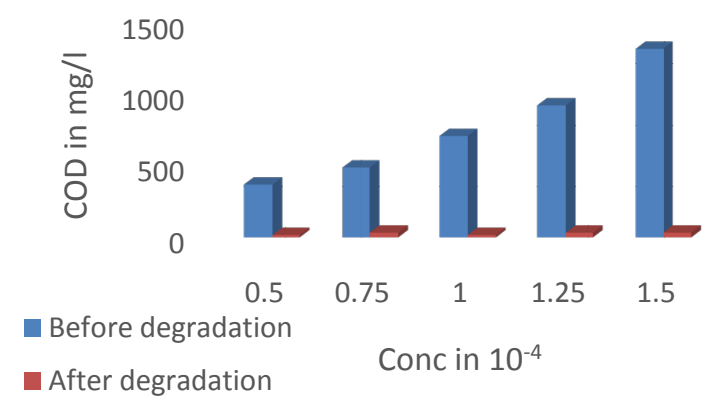

Figure 15. Effect of concentration of IC on COD for the degradation in sunlight.

react, respectively, with electron acceptors and donorsthat happen to be adsorbed on the semiconductor surface or within the surrounding electrical double layer of the charged nanoparticles. In the absence of suitable $\mathrm{e}^{-} / \mathrm{h}^{+}$ scavengers the stored energy is dissipated within a few nanoseconds by recombination. If a suitable scavenger or surface defect state is available to trap the electron or hole, recombination is prevented and subsequent redox reactions may occur. As the number of defects in $\mathrm{ZnO} / \mathrm{Nb}_{2} \mathrm{O}_{5}$ nanoparticles, electron or hole recombination is prevented and therefore the $\mathrm{ZnO} / \mathrm{Nb}_{2} \mathrm{O}_{5}$ is very active under $\mathrm{UV}$ light compared to bare $\mathrm{ZnO}$.

\section{Reuse of the Photocatalyst}

The possibility of reusing the photocatalyst was examined to see the cost effectiveness of the method. After the degradation of the dye, the dye solution was kept standing for $10 \mathrm{hrs}$ and then the supernatant was decanted. The photocatalyst was then thoroughly washed with double distilled water and reused for degradation with fresh of dye solution. It was observed that the photocatalytic efficiency was slightly decreased to approximately $80 \%$ for the use of second time. Further use of the catalyst showed lesser efficiency.

\section{Biological Activities}

Niobium doped ZnO nanoparticles synthesised by the electrochemical method were tested for antibacterial activity by Discdiffusion method against different bacteria. The pure bacterial culture was subculture on nutrient agar media. The activity was compared against standard gentamycin (+ve) control and (-ve) control. The solutions was prepared by dissolving $1.0 \mathrm{mg}$ in $100 \mu \mathrm{DMSO}$ and was made up to $1 \mathrm{ml}$ by methanol, which gives the concentration of $1 \mathrm{mg} / \mathrm{ml}$ and $30 \mu \mathrm{l}$ of each solution was placed on a disc. After incubation for $48 \mathrm{hrs}$ at $37^{\circ} \mathrm{C}$, the different levels of zone inhibition in $\mathrm{mm}$ around $\mathrm{ZnO} / \mathrm{Nb}_{2} \mathrm{O}_{5}$ nanoparticles was measured which is as shown in Figure 16 and Table 7. Hence $\mathrm{ZnO} / \mathrm{Nb}_{2} \mathrm{O}_{5}$ nanoparticles shows very good inhibition compared to $+\mathrm{Ve}$ and -Ve control. 


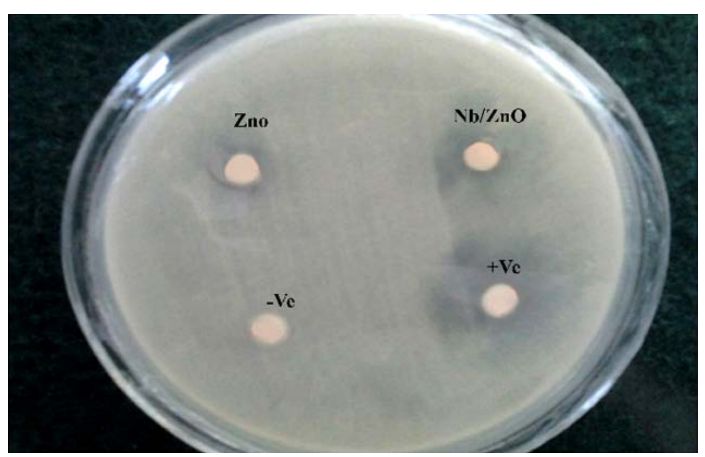

(a)

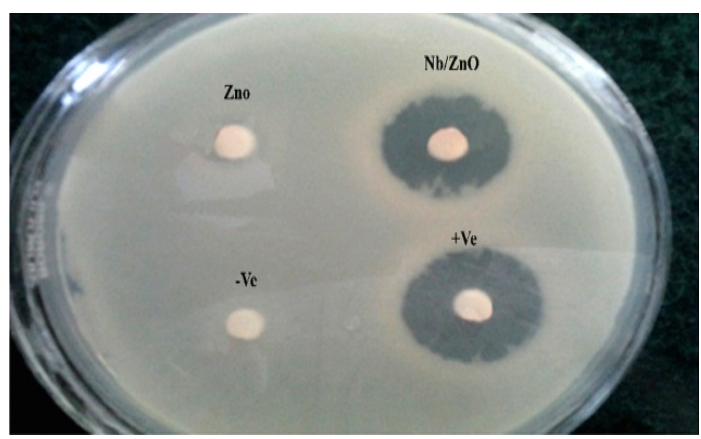

(c)

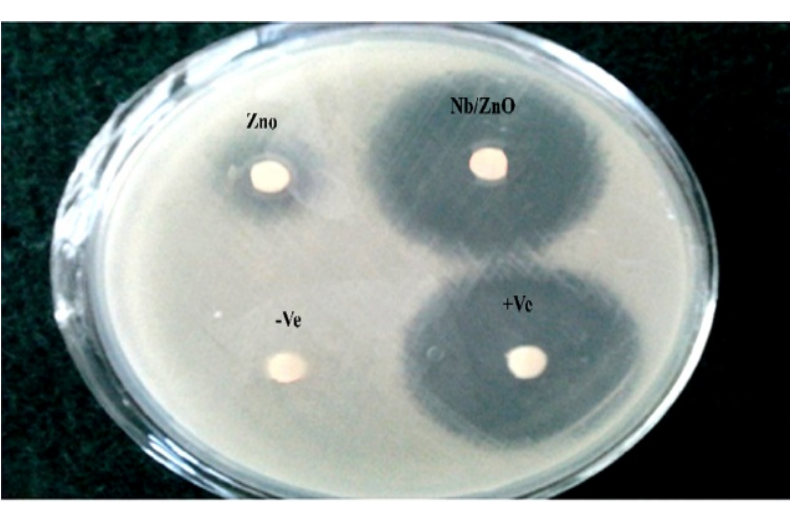

(e)

Figure 16. (a) Escherichia coli; (b) Xanthomonas oryzae; (c) Salmonella typhii; (d) Enterobacter aerogens; (e) Pseudomonas aregunosa.

Table 7. Zone of inhibition (mm) of $\mathrm{ZnO} / \mathrm{Nb}_{2} \mathrm{O}_{5}$ nanoparticles.

\begin{tabular}{ccccc}
\hline Test organisms & $\mathbf{Z n O}$ & $\mathbf{Z n O} / \mathbf{N b}_{\mathbf{2}} \mathbf{O}_{\mathbf{5}}$ & $+\mathbf{V e}$ & $-\mathbf{V e}$ \\
\hline Escherichia coli & 0.9 & 1.9 & 2.1 & 0 \\
Xanthomonas oryzae & 0.4 & 1.0 & 1.2 & 0 \\
Salmonella typhii & 0.5 & 0.8 & 1.0 & 0 \\
Enterobacter aerogens & 0.8 & 1.9 & 2.2 & 0 \\
Pseudomonas aregunosa & 0.4 & 0.7 & 1.0 & 0 \\
\hline
\end{tabular}

\section{Conclusion}

$\mathrm{ZnO} / \mathrm{Nb}_{2} \mathrm{O}_{5}$ nanoparticles were synthesised by electrochemical method an environment friendly method. These

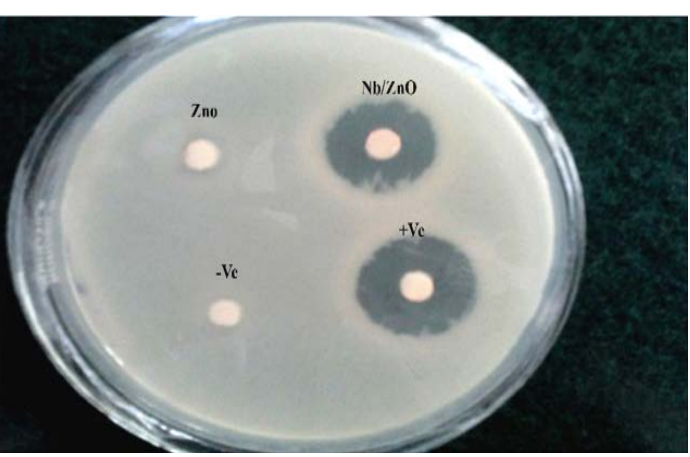

(b)

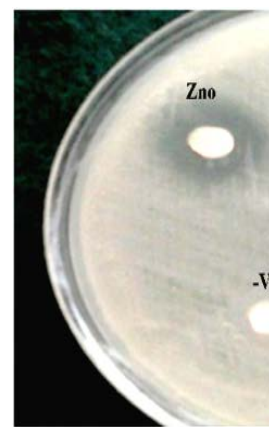

$\mathrm{Nb} / \mathrm{Hn} 0$

$+\mathrm{Ve}$

(d) 
nanoparticles were characterised by UV, IR, SEM, XRD, ICPMS and EDAX analysis. Photodegradation by these semiconductors offers a green technology for the removal of hazardous compounds present in the industrial effluents. Kinetics for the degradation of indigocarmine by $\mathrm{ZnO} / \mathrm{Nb}_{2} \mathrm{O}_{5}$ nanoparticles were studied systematically. The completion of degradation was confirmed by COD experiment. Results of COD revealed that $96 \%$ of the dye had been degraded. These nanoparticles act as a very good catalyst for the degradation of dye and a promising antibacterial agent.

\section{References}

[1] Djurisic, A.B. (2002) Progress in the Room-Temperature Optical Functions of Semiconductors. Materials Science and Engineering: R: Reports, 38, 237-293. http://dx.doi.org/10.1016/S0927-796X(02)00063-3

[2] Dong, L.F., Jiao, J., Tuggle, D.W., Petty, L.M. and Elliff, S.A. (2003) ZnO Nanowires Formed on Tungsten Substrates and Their Electron Field Emission Properties. Applied Physics Letters, 82, 1096-1098. http://dx.doi.org/10.1063/1.1554477

[3] Zhu, B.L., Xie, C.S., Wang, A.H., Wu, J., Wu, R. and Liu, J. (2007) Laser Sintering ZnO Thick Films for Gas Sensor Application. Journal of Materials Science, 42, 5416-5420. http://dx.doi.org/10.1007/s10853-006-0768-2

[4] Agarwal, G. and Speyer, R.F. (1998) Current Change Method of Reducing Gas Sensing Using ZnO Varistors. Journal of Electrochemical Society, 145, 2920-2925. http://dx.doi.org/10.1149/1.1838737

[5] Kind, H., Yan, H., Messer, B., Law, M. and Yang, P. (2002) Nanowire Ultraviolet Photodetectors and Optical Switches. Advanced Materials, 14, 158-160. http://dx.doi.org/10.1002/1521-4095(20020116)14:2<158::AID-ADMA158>3.0.CO;2-W

[6] Byrappa, K., Subramani, A.K., Ananda, S., Lakanatharai, K.M., Sunitha, M.H., Basavalingu, B. and Soga, K. (2006) Impregnation of $\mathrm{ZnO}$ onto Activated Carbon under Hydrothermal Conditions and Its Photocatalytic Properties. Journal of Materials Science, 41, 1355-1362. http://dx.doi.org/10.1007/s10853-006-7341-X

[7] Xu, F., Zhang, P., Navrotsky, A., Yuan, Z.Y., Ren, T.Z., Halasa, M. and Su, B.L. (2007) Hierarchically Assembled Porous ZnO Nanoparticles: Synthesis, Surface Energy, and Photocatalytic Activity. Chemistry of Materials, 19, 56805686. http://dx.doi.org/10.1021/cm071190g

[8] Cernigoj, U., Stangar, U.L., Trebse, P., Krasovec, U.O. and Gross, S. (2006) Photocatalytically Active TiO 2 Thin Films Produced by Surfactant-Assisted Sol-Gel Processing. Thin Solid Films, 495, 327-332. http://dx.doi.org/10.1016/j.tsf.2005.08.240

[9] Yu, H., Zhang, K. and Rossi, C. (2007) Theoretical Study on Photocatalytic Oxidation of VOCs Using $\mathrm{Nano}^{-T i O}{ }_{2}$ Photocatalyst. Journal of Photochemistry and Photobiology A, 188, 65-83. http://dx.doi.org/10.1016/j.jphotochem.2006.11.021

[10] Lizama, C., Freer, J., Baeza, J. and Mansilla, H.D. (2002) Optimized Photodegradation of Reactive $\mathrm{Blue}_{19}$ on $\mathrm{TiO}_{2}$ and ZnO Suspensions. Catalysis Today, 76, 235-246. http://dx.doi.org/10.1016/S0920-5861(02)00222-5

[11] Peng, F., Wang, H., Yu, H. and Chen, S. (2006) Preparation of Aluminum Foil-Supported Nano-Sized, ZnO and Its Photocatalytic Phenol under Visible Light Irradiation. Materials Research Bulletin, 41, 2123-2129. http://dx.doi.org/10.1016/j.materresbull.2006.03.029

[12] Ahmadipour, M., Hatami, M. and Rao, K.V. (2012) Preparation and Characterization of Nano-Sized $\left(\mathrm{Mg}_{(\mathrm{x})} \mathrm{Fe}_{(1-\mathrm{x})} \mathrm{O} /\right.$ $\left.\mathrm{SiO}_{2}\right)(\mathrm{x}=0.1)$ Core-Shell Nanoparticles by Chemical Precipitation Method. Advances in Nanoparticles, 1, 37-43.

[13] Qiu, X.Q., Li, G.S., Sun, X.F., Li, L.P. and Fu, X.Z. (2008) Doping Effects of $\mathrm{Co}^{2+}$ Ions on ZnO Nanorods and Their Photocatalytic Properties. Nanotechnology, 19, Article ID: 215703. http://dx.doi.org/10.1088/0957-4484/19/21/215703

[14] Marci, G., Augugliaro, V., López-Muñoz, M.J., Martin, C., Palmisano, L., Rives, V., Schiavello, M., Tilley, R.J.D. and Venezia, A.M. (2001) Preparation Characterization and Photocatalytic Activity of Polycrystalline $\mathrm{ZnO} / \mathrm{TiO}{ }_{2}$ Systems. 2. Surface, and Bulk Characterization, and 4-Nitrophenol Photodegradation in Liquid-Solid Regime. Journal of Physical Chemistry B, 105, 1033-1040. http://dx.doi.org/10.1021/jp003173j

[15] Ullah, R. and Dutta, J. (2008) Photocatalytic Degradation of Organic Dyes with Manganese-Dopeded ZnO Nanoparticles. Journal of Hazardous Materials, 156, 194-200. http://dx.doi.org/10.1016/j.jhazmat.2007.12.033

[16] Zhang, Q., Fan, W. and Gao, L. (2007) Anatase $\mathrm{TiO}_{2}$ Nanoparticles Immobilized on ZnO Tetrapods as a Highly Efficient and Easily Recyclable Photocatalyst. Applied Catalysis B: Environmental, 76, 168-173. http://dx.doi.org/10.1016/j.apcatb.2007.05.024

[17] Anandan, S., Vinu, A., Lovely, K.L.P.S., Gokulakrishnan, N., Srinivasu, P., Mori, T., Murugesan, V., Sivamurugan, V. and Ariga, K. (2007) Photocatalytic Activity of La-Diped ZnO for the Degradation of Monocrotophos in Aqueous Suspension. Journal of Molecular Catalysis A: Chemical, 266, 149-157. http://dx.doi.org/10.1016/j.molcata.2006.11.008

[18] Li, D. and Haneda, H. (2003) Photocatalysis of Sprayed Nitrogen-Containing $\mathrm{Fe}_{2} \mathrm{O}_{3}-\mathrm{ZnO}$ and $\mathrm{WO}_{3}-\mathrm{ZnO}_{\mathrm{Composite}}$ 
Powders in Gas-Phase. Journal of Photochemistry and Photobiology A: Chemistry, 160, 203-212. http://dx.doi.org/10.1016/S1010-6030(03)00212-0

[19] Ekambaram, S., Likubo, Y. and Kudo, A. (2007) Combustion Synthesis and Photocatalytic Properties of Transition Metal-Incorporated ZnO. Journal of Alloys and Compounds, 433, 237-240. http://dx.doi.org/10.1016/j.jallcom.2006.06.045

[20] Lin, H.F., Liao, S.C. and Hung, S.W. (2005) The dc Thermal Plasma Synthesis of ZnO Nanoparticles for Visible-Light Photocatalyst. Journal of Photochemistry and Photobiology A: Chemistry, 174, 82-87. http://dx.doi.org/10.1016/j.jphotochem.2005.02.015

[21] Nyffenegger, R.M., Craft, B., Shaaban, M., Gorer, S., Erley, G. and Penner, R.M. (1998) A Hybrid Electrochemical/ Chemical Synthesis of Zinc Oxide Nanoparticles and Optically Intrinsic Thin Films. Chemistry of Materials, 10, 11201129. http://dx.doi.org/10.1021/cm970718m

[22] Therese, G.H.A. and Kamath, P.V. (2000) Electrochemical Synthesis of Metal Oxides and Hydroxides. Chemistry of Materials, 12, 1195-1204. http://dx.doi.org/10.1021/cm990447a

[23] Byrappa, K., Subramani, A.K., Ananda, S., Rai, K.M.L., Dinesh, R. and Yoshimura, M. (2006) Photocatalytic Degradation of Rhodamine B Dye Using Hydrothermally Synthesized ZnO. Bulletin of Materials Science, 29, 433-438. http://dx.doi.org/10.1007/BF02914073

[24] Belever, C., Adán, C. and Fernández-García, M. (2009) Photocatalytic Behaviour of $\mathrm{Bi}_{2} \mathrm{MO}_{6}$ Polymetalates for Rhodamine B Degradation. Catalysis Today, 143, 274-281. http://dx.doi.org/10.1016/j.cattod.2008.09.011

[25] Carp, O., Huisman, C.L. and Rellar, A. (2004) Photoinduced Reactivity of Titanium Dioxide. Progress in Solid State Chemistry, 32, 33-177. http://dx.doi.org/10.1016/j.progsolidstchem.2004.08.001

[26] Sclafani, A. and Hermann, J.M. (1998) Influence of Metallic Silver and of Platinum-Silver Bimetallic Deposits on the Photocatalytic Activity of Titania (Anatase and Rutile) in Organic and Aqueous Media. Journal of Photochemistry and Photobiology A: Chemistry, 113, 118-188. http://dx.doi.org/10.1016/S1010-6030(97)00319-5

[27] Rodriguez, J.A. and Fernández-García, M. (2007) Synthesis Proparties and Applications of Oxide Nanomaterials. John Wiley and Sons, Inc., New York, 335-351. http://dx.doi.org/10.1002/0470108975

[28] Li, X., Han, X., Wang, W., Liu, X., Wang, Y. and Liu, X. (2012) Synthesis, Characterization and Photocatalytic Activity of Nb-Doped $\mathrm{TiO}_{2}$ Nanoparticles. Advanced Materials Research, 455, 110-111.

[29] Lakshmi, G.C., Ananda, S., Somashekar, R. and Ranganathaiah, C. (2012) Synthesis of ZnO/MgO Nanocomposites by Electrochemical Method for Photocatalytic Degradation Kinetics of Eosin Yellow Dye. International Journal of NanoScience and Nanotechnology, 3, 47-63.

[30] Patil, A.V., Dighavkar, C.G., Sonawane, S.K., Patil, S.J. and Borse, R.Y. (2010) Influence of $\mathrm{Nb}_{2} \mathrm{O}_{5} \mathrm{Doping}_{\text {on } \mathrm{ZnO}}$ Thick Film Gas Sensors. Journal of Optoelectronics and Advanced Materials, 12, 125-1261.

[31] Pail, D.R., Patil, L.A. and Amalnerkar, D.P. (2007) Ethanol Gas Sensing Properties of $\mathrm{Al}_{2} \mathrm{O}_{3}$-Doped ZnO Thick Film Resistors. Bulletin of Materials Science, 30, 553-559. http://dx.doi.org/10.1007/s12034-007-0086-6

[32] Wei, L., Shifu, C., Wei, Z. and Sujuan, Z. (2009) Titanium Dioxide Mediated Photocatalytic Degradation of Mathamidophos in Aqueous Phase. Journal of Hazardous Materials, 164, 154-160.

http://dx.doi.org/10.1016/j.jhazmat.2008.07.140 
Scientific Research Publishing (SCIRP) is one of the largest Open Access journal publishers. It is currently publishing more than 200 open access, online, peer-reviewed journals covering a wide range of academic disciplines. SCIRP serves the worldwide academic communities and contributes to the progress and application of science with its publication.

Other selected journals from SCIRP are listed as below. Submit your manuscript to us via either submit@scirp.org or Online Submission Portal.
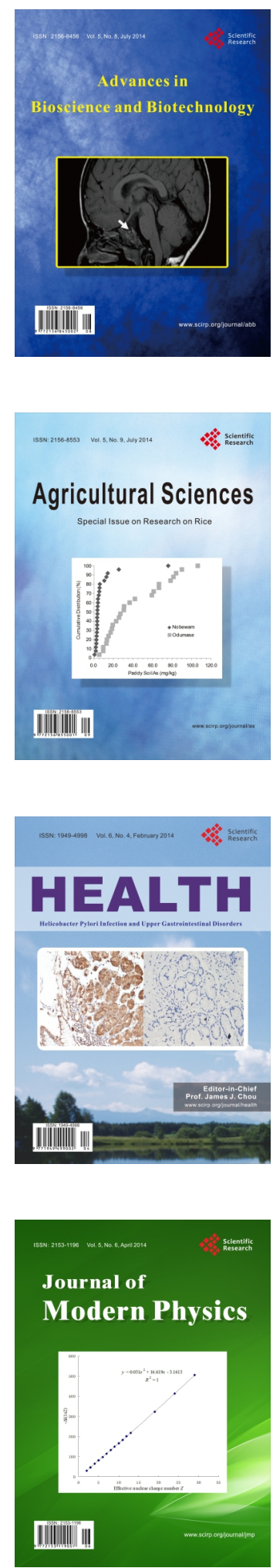
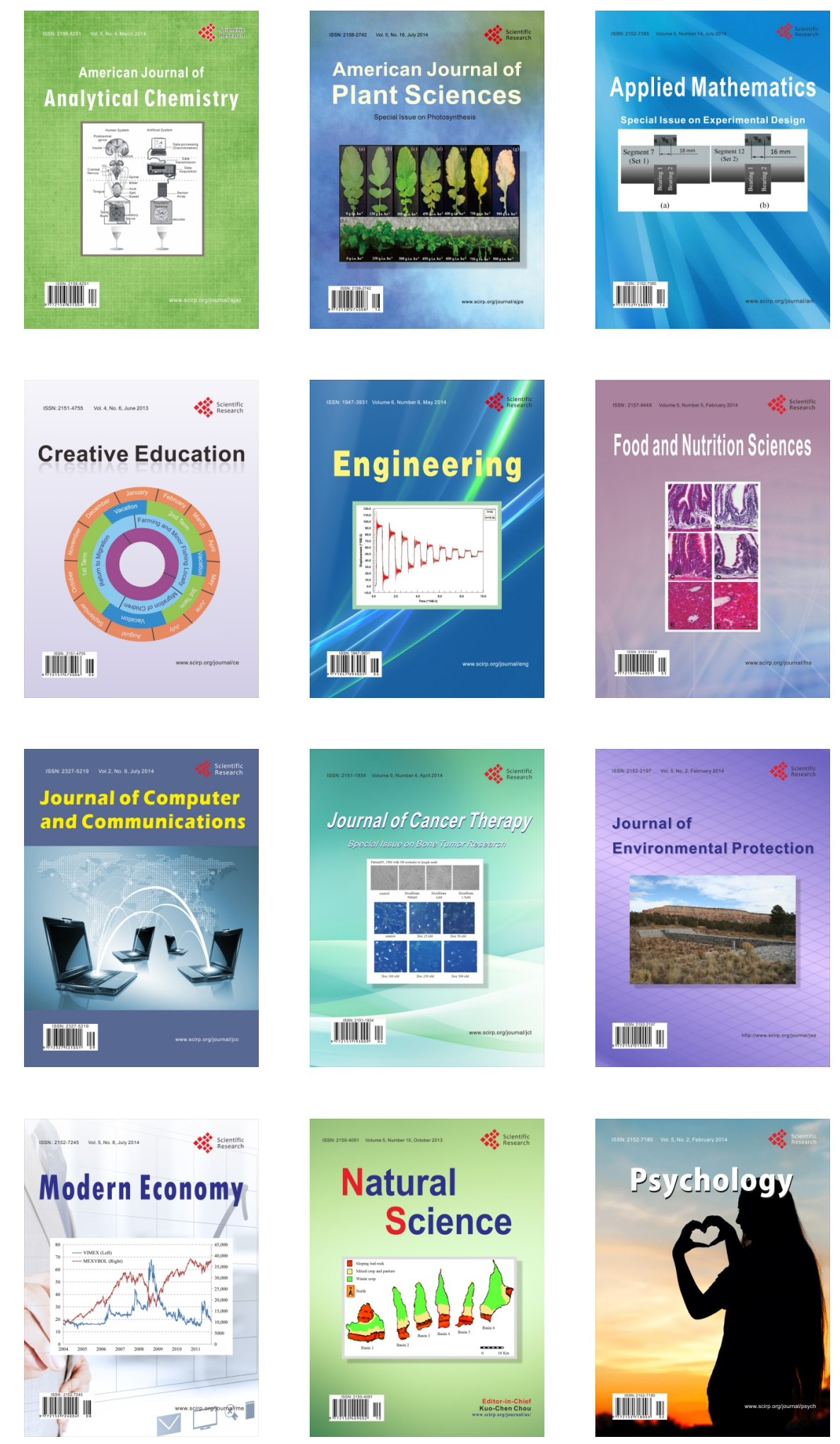